Ferdian Achsani: Kesalahan Berbahasa pada Penulisan Berita Online Sorot Sukoharjo...

\title{
KESALAHAN BERBAHASA PADA PENULISAN BERITA ONLINE SOROT SUKOHARJO EDISI MEI 2019
}

\author{
Errors in Language Writing Online Sorot Sukoharjo News Edition May 2019
}

\author{
Ferdian Achsani \\ SMP Negeri 1 Weru \\ Jalan Kapten Patimura 03, Karangmojo, Weru, Sukoharjo, Jawa Tengah \\ Pos-el: dwikurniawan219@gmail.com
}

Naskah masuk: 2 Februari 2020, disetujui: 21 Juni 2020, revisi akhir: 22 Desember 2020

\begin{abstract}
Abstrak
Berita merupakan salah satu laporan peristiwa yang bersifat faktual dan akurat sehingga dalam menulis berita perlu memperhatikan kaidah kebahasaan yang baik dan benar. Namun, hal tersebut belum tecermin dalam media berita online Sorot Sukoharjo. Masih ditemukan beberapa kesalahan berbahasa dalam penulisan berita di media online tersebut. Penelitian ini bertujuan untuk menganalisis kesalahan berbahasa pada penulisan media berita online Sorot Sukoharjo. Penelitian ini termasuk dalam jenis deskriptif kualitatif. Pengumpulan data dilakukan dengan menggunakan teknik baca dan catat, yaitu peneliti membaca berita-berita di media daring Sorot Sukoharjo edisi Mei 2019. Kemudian, peneliti mencatat kesalahan berbahasa yang ditemukan pada penulisan berita yang diunggah. Hasil dari penelitian ini dapat disimpulkan bahwa kesalahan-kesalahan berbahasa dalam penulisan berita di media Sorot Sukoharjo meliputi tataran sintaksis 13 data, tataran ejaan 25 data, dan kesalahan tataran fonologi 15 data. Berdasarkan uraian tersebut dapat disimpulkan bahwa kesalahan ejaan merupakan kesalahan berbahasa yang paling dominan dalam penulisan berita di media online Sorot Sukoharjo.
\end{abstract}

Kata kunci: kesalahan berbahasa, berita media online, Sorot Sukoharjo

\begin{abstract}
News is one of the factual and accurate reports, therefore it is necessary to use a good and correct language rules in writing news. However, this has not been reflected in some online news media. Several language errors in writing news still found in the online media. This study aims to analyze language errors in writing online news media, precisely in Sorot Sukoharjo. This research is classified as a qualitative descriptive type. Data collection was carried out using reading and note-taking techniques. Furthermore, the researcher reading the news in the May 2019 edition of Sorot Sukoharjo online media then recording the language errors found in the uploaded news. Based on the research results, it can be concluded that the language errors in the Sorot Sukoharjo media include syntactic level of 13 data, spelling level of 25 data, and phonological level error of 15 data. Therefore, it can be concluded that spelling are the most dominant language errors in writing news on the Sorot Sukoharjo online media.
\end{abstract}

Keywords: language errors, online media news, Sorot Sukoharjo

\section{PENDAHULUAN}

Kebutuhan manusia akan informasi berita seakan menjadi barang pokok yang harus selalu terpenuhi. Kehadiran informasi bagi sejumlah orang sangat dibutuhkan demi mendapatkan pengetahuan terkait apa yang sedang terjadi di lingkungan sekitar, bahkan dunia. Manusia membutuhkan informasi tersebut agar tidak ketinggalan zaman. Munculnya media massa online menjadi salah satu alternatif bagi sejumlah orang untuk mempermudah mendapatkan informasi. 
Ferdian Achsani: Kesalahan Berbahasa pada Penulisan Berita Online Sorot Sukoharjo...

Informasi menjadi mudah diakses di mana dan kapan saja. Kecanggihan teknologi online ini menjadikan beberapa orang untuk beralih dari penggunaan berita informasi yang semula koran cetak menjadi media yang berbasis digital.

Keunikan dari adanya media informasi berita yang berbasis digital adalah mudahnya mengakses informasi secara cepat. Biasanya, seseorang harus menunggu hari berikutnya demi mendapatkan informasi yang terjadi saat ini. Misalnya, untuk memperoleh infomrasi berita duka meninggalnya sang maestro the godfather of broken heart pada 5 Mei lalu, masyarakat lebih mudah mendapatkannya melalui media massa berbasis digital tanpa harus menunggunya di hari berikutnya. Kehadiran media massa online memudahkan setiap orang untuk bertukar informasi berita, baik itu para wartawan ataupun nonwartawan. Penggunan media massa sebagai salah satu penyalur informasi berita menjadikan definisi berita kian terealisasi dengan tepat.

Muhtadi (2016:87) mengungkapkan bahwa berita merupakan serangkain laporan peristiwa baru yang bersifat fakta dan bertujuan untuk menambah pengetahuan bagi pembaca. Dari pengertian tersebut dapat dipahami bahwa berita pada umumnya harus bersifat baru atau news, dan segar atau fresh. Suatu laporan berita yang sudah terjadi saat ini belum tentu laporan berita tersebut tergolong baru jika dibaca besok atau bahkan lusa. Berita meninggalnya Didi Kempot pada 5 Mei yang terlihat baru dan fresh akan terlihat basi bila didengar atau dibaca pada beberapa bulan ke depan. Dengan demikian, media massa daring sebagai penyalur informasi berita secara cepat kepada masyarakat sangat berperan penting.

Penulisan berita harus menggunakan bahasa yang baik dan benar sesuai dengan kaidah kebahasaan dengan tujuan agar informasi yang disampaikan kepada masyarakat dapat tersampaikan dengan jelas. Bahasa Indonesia yang baik adalah bahasa Indonesia yang digunakan sesuai dengan norma kemasyarakatan yang berlaku. Misalnya, dalam situasi santai di pasar, di toko, dapat menggunakan bahasa santai. Dalam situasi resmi seperti seminar, dan pidato hendaknya menggunakan bahasa resmi dan formal dengan memperhatikan norma bahasa yang ada. Menurut Kusumaningsih, dkk (2013: 20), bahasa Indonesia yang baik dan benar adalah bahasa yang digunakan sesuai dengan aturan atau kaidah bahasa Indonesia yang baku. Kaidah itu meliputi kaidah ejaan, pembentukan kata, penyusunan paragraf, dan penataan penalaran.

Penulisan berita yang tidak memperhatikan kaidah penggunaan bahasa akan berpengaruh terhadap pemahaman berita. Informasi yang disampaikan akan terlihat kabur, ambigu, atau taksa apabila terjadi kesalahan berbahasa dalam penulisan laporan berita. Untuk itulah kesalahan berbahasa pada sebuah laporan berita seharusnya dapat dihindari. Sebagai salah satu media tulis yang terkenal dengan keakuratannya, penulisan berita seharusnya patuh terhadap kaidah penggunaan bahasa baku yang berlaku. Akan tetapi, tidak selalu bahasa jurnalistik harus bersifat baku. Misalnya, ketika wartawan melakukan wawancara terhadap masyarakat yang menggunakan ragam bahasa santai dan menuangkannya ke dalam bentuk tulisan, tentu tidak mungkin wartawan akan mengubah bahasa tersebut ke dalam bahasa baku.

Sorot Sukoharjo merupakan salah satu media berita berbasis online yang menyoroti berita-berita terbaru dan terkini khusus di Kabupaten Sukoharjo. Media ini selalu menampilkan berita-berita terkini yang sedang trending di Kabupaten Sukoharjo. Dalam penulisan berita ini masih ditemukan beberapa kesalahan berbahasa. Hal ini menjadikan peneliti tertarik untuk mengkaji kesalahan-kesalahan berbahasa di media berita online tersebut.

Kesalahan berbahasa sering terjadi karena tidak semua orang mampu menerapkan kaidah kebahasaan yang baik dan benar 
Ferdian Achsani: Kesalahan Berbahasa pada Penulisan Berita Online Sorot Sukoharjo...

dalam kehidupan sehari-hari. Masih banyak orang yang tidak menyadari akan kesalahan berbahasa yang sering digunakan. Misalnya, kita sering menemukan kesalahan ketik atau tulis. Hal ini disebabkan oleh kurangnya konsentrasi seseorang dalam menulis atau bisa juga disebabkan kurangnya pemahaman terhadap penggunaan bahasa Indonesia yang baik dan benar.

Kesalahan seperti ini dapat dikatakan sebagai wujud kesalahan dalam berbahasa. Kesalahan berbahasa merupakan salah satu bentuk penggunaan bahasa yang kurang tepat. Menurut Setyawati (2010: 13) kesalahan berbahasa adalah penggunaan bahasa baik secara lisan maupun tulisan yang menyimpang dari faktor-faktor penentu berkomunikasi atau menyimpang dari norma kemasyarakatan dan menyimpang dari kaidah tata bahasa Indonesia. Ramaniyar (2017:71) menyebutkan bahwa kesalahan berbahasa terjadi karena faktor seperti pengaruh kemampuan kebahasaan seseorang, kekurangpahaman pemakaian kaidah kebahasaan, dan pengajaran bahasa yang kurang tepat. Analisis kesalahan berbahasa merupakan studi kasus kebahasaan yang mengkaji pengunaan bahasa oleh para pengguna yang kurang tepat. Analisis kesalahan berbahasa bertujuan untuk memberikan pemahaman terhadap pembaca mengenai penggunaan kaidah kebahasaan yang baik dan benar.

Analisis kesalahan berbahasa juga dapat dikatakan sebagai suatu bentuk sikap protes terhadap penggunaan bahasa masyarakat yang masih menyimpang dari aturan penggunaan kaidah kebahasaan yang baik dan benar. Adanya analisis kesalahan berbahasa ini dapat digunakan untuk mengungkapkan bentuk-bentuk kesalahan berbahasa yang digunakan oleh seseorang dalam menggunakan bahasa sebagai alat untuk berkomunikasi. Umumnya, kesalahan tersebut disebabkan oleh pengguna bahasa yang tidak sengaja ataupun pengguna bahasa yang tidak tahu tentang penggunaan kaidah kebahasaan. Kesalahan berbahasa juga dapat terjadi karena pengguna mengetahui kaidah kebahasaan, tapi tidak menerapkannya. Darsita (2014:246-247) mengungkapkan bahwa faktor penyebab kesalahan berbahasa juga disebabkan oleh kemampuan seseorang dalam menguasai lebih dari satu bahasa atau disebut sebagai multilingual.

Tujuan analisis kesalahan berbahasa bukan menjatuhkan suatu objek yang dikaji sebagai bahan analisis. Tujuan dari analisis kesalahan tak lain memberikan pengajaran penggunaan berbahasa yang baik dan benar terhadap objek dan masyarakat agar lebih baik lagi dalam penggunaan kaidah kebahasaan. Analisis kesalahan berbahasa dapat dikatakan sebagai teknik untuk mencatat dan mengklasifikasikan kesalahankesalahan yang dibuat seseorang dan memberikan pembetulan terhadap kesalahan-kesalahan tersebut. Bentuk kesalahan berbahasa yang terjadi salah satunya adalah pelanggaran terhadap kode atau kaidah bahasa. Pelanggaran tersebut bukan bersifat fisik, tetapi tanda kurang sempurnanya pengetahuan terhadap kode atau kaidah bahasa (Widianingsih, 2014:5). Penelitian terhadap analisis kesalahan berbahasa bertujuan untuk meningkatkan kualitas masyarakat dalam menerapkan kaidah berbahasa tulis (Oktaviani, Muhammad, Purwadi, 2018: 98).

Dalam perkembangan studi linguistik, kesalahan berbahasa ini dibagi menjadi sejumlah tataran, yaitu tataran fonologi, morfologi, sintaksis, semantik, dan ejaan. Tataran fonologi mengkaji penggunaan kesalahan bahasa yang mengalami kesalahan fonem dan diftong, morfologi mengkaji penggunaan bahasa dari segi satuan-satuan dasar bahasa sebagai satuan gramatikal. Sintaksis mengkaji tata dan struktur kata bahasa dalam sebuah kalimat; semantik mengkaji penggunaan makna dalam bahasa dan ejaan mengkaji penggunaan kata yang sesuai dengan PUEBI.

Dari uraian tersebut, peneliti ingin mengkaji analisis kesalahan berbahasa pada penulisan media berita online Sorot Sukoharjo. Penelitian terkait analisis kesalahan 
Ferdian Achsani: Kesalahan Berbahasa pada Penulisan Berita Online Sorot Sukoharjo...

berbahasa pernah dilakukan oleh Nurida (2016). Penelitian yang dilakukan Nurida (2016) dalam mengkaji surat kabar Kendari Pos edisi Mei 2016 menyimpulkan bahwa setelah dilakukan analisis, kesalahan berbahasa terbanyak terjadi dalam tataran morfologi. Hal ini terlihat pada tingginya jumlah kesalahan penulisan preposisi dan afiksasi. Secara keseluruhan, tulisan ini sama dengan penelitian yang akan dilakukan Nurida (2016), yaitu mengkaji analisis kesalahan berbahasa pada media berita. Perbedaan penelitian hanya terlihat dalam objek kajian yang diteliti. Pada penelitian sebelumnya objek kajian penelitian adalah surat kabar Kendari Pos edisi Mei 2016, sedangkan pada penelitian ini objek kajian penelitian adalah teks berita dari media daring Sorot Sukoharjo edisi Mei 2019. Penelitian ini perlu dilakukan untuk mengetahui bahwa kesalahan berbahasa pada media massa tidak hanya dijumpai pada satu objek tertentu tetapi juga berbagai objek lainnya.

\section{METOdE PENELITIAN}

Penelitian ini termasuk dalam penelitian deskriptif kualitatif. Bugin (2003:41) menyatakan bahwa penelitian kualitatif tidak bermaksud untuk menggambarkan karakteristik populasi, melainkan lebih terfokus pada representasi terhadap fenomena sosial. Hal ini dapat dipahami bahwa penelitian kualitatif merupakan penelitian yang merepresentasikan fenomena-fenomena sosial yang dideskripsikan dalam sebuah narasi. Meskipun demikian, Mahsun (2012:31) menegaskan bahwa penelitian kualitatif juga tidak menutup kemungkinan pemanfaatan data kuantitatif, misalnya untuk pengembangan data penelitian. Pengumpulan data yang dilakukan dalam peneltian ini adalah menggunakan teknik baca dan catat. Peneliti membaca setiap berita yang diunggah di media daring Sorot Sukoharjo edisi Mei 2019. Kemudian, peneliti mencatat kesalahan-kesalahan berbahasa dan mengklasifikannya ke dalam domain-domain analisis kesalahan berbahasa. Data yang ditampilkan dalam penelitian ini dipilih secara acak dan dapat mewakili dari data-data yang lainnya.

\section{HASIL DAN PEMBAHASAN}

Setelah dilakukan pembacaan dan observasi terhadap beberapa artikel berita yang dipublikasi pada media daring Sorot Sukoharjo, peneliti menemukan beberapa kesalahan sebagai berikut.

Tabel 1 Jumlah Kesalahan Berbahasa

\begin{tabular}{lc}
\hline \multicolumn{1}{c}{ Kesalahan } & Jumlah Data \\
\hline Fonologi & 17 \\
\hline Morfologi & 3 \\
\hline Ejaan & 25 \\
\hline Sintaksis & 13 \\
\hline Semantik & - \\
\hline
\end{tabular}

\subsection{Kesalahan Sintaksis}

\subsubsection{Kesalahan Kata}

\section{Data 1}

Dimulai dimulai dari perkampungan menempuh jarak sekitar dua kilometer menuju Balai Desa Trangsan.

Kesalahan berbahasa tataran sintaksis pada kalimat tersebut terdapat pada penulisan kata dimulai. Pada kalimat tersebut, penggunaan kata dimulai ditulis dua kali yang pada intinya memiliki kesamaan makna kata. Dalam suatu kalimat hendaknya penulisan kata ditulis satu kali apabila kata tersebut memiliki maksud yang sama dan tidak termasuk dalam reduplikasi. Selain itu, dalam kalimat tersebut juga tidak terdapat subjek kalimat. Kalimat tersebut merupakan penegasan dari kalimat sebelumnya yang ingin menegaskan dimulainya kegiatan grebeg penjalin. Pembetulan terhadap kesalahan berbahasa tersebut dapat dilihat sebagai berikut.

Kegiatan tersebut dimulai dari perkampungan menempuh jarak sekitar dua kilometer menuju Balai Desa Trangsan. 
Ferdian Achsani: Kesalahan Berbahasa pada Penulisan Berita Online Sorot Sukoharjo...

\subsubsection{Kesalahan Penggunaan Subjek}

Data 2

Selain itu, pekerja dia juga menuntut untuk penghapusan sistem kontrak terhadap buruh dan pemberian fasilitas BPJS baik kesehatan maupun ketenagakerjaan.

Dalam suatu kalimat, hendaknya menggunakan subjek yang jelas agar kalimat mudah untuk dipahami. Begitu juga pada penggunaan subjek dalam bahasa jurnalistik juga harus memiliki subjek kalimat. Penggunaan subjek ganda pada kalimat di atas menjadikan kesalahan berbahasa pada tataran sintaksis. Penggunaan kata pekerja dan dia pada kalimat tersebut bertujuan untuk menjelaskan pelaku dari aksi demo. Kalimat tersebut lebih tepat apabila subjek yang digunakan adalah pekerja dan menghilangkan kata dia. Selain itu, penggunaan preposisi untuk juga perlu dihilangkan agar kalimat tidak terkesan bertele-tele. Pembetulan terhadap kalimat tersebut dapat dilihat sebagai berikut.

Selain itu, pekerja juga menuntut penghapusan sistem kontrak terhadap buruh dan pemberian fasilitas BPJS baik kesehatan maupun ketenagakerjaan.

\section{Data 3 \\ 3.1.3 Kesalahan Konjungsi}

Nur Rahma diduga melanggar undangundang Pasal 521 yang berbunyi setiap pelaksana, peserta dan atau tim kampanye yang dengan sengaja melanggar larangan kampanye seperti yang dimaksud pasal 280 ayat 1 . Caleg dari DPR RI dari Partai Gerindra yang melakukan kegiatan kampanye di Masjid Baitus Syukur di Desa Gonilan, Kecamatan Kartasura beberapa waktu lalu.

Paragraf di atas termasuk dalam kesalahan berbahasa pada tataran sintaksis. Penggunaan kata dari yang berlebihan pada data di atas mengakibatkan Kalimat (2) tidak efektif sehingga salah satu konjungsi dari yang terdapat pada kalimat tersebut harus dihilangkan. Selain itu, penggunaan konjungsi yang pada kalimat tersebut juga harus dihilangkan agar kalimat menjadi efektif. Penggunaan kata yang pada kalimat tersebut menyebabkan kalimat tidak lengkap karena pada intinya pada kalimat tersebut ingin menjelaskan tentang kapan dan di mana Nur Rahma melakukan pelanggaran. Untuk itu, penggunaan konjungsi yang dapat diganti dengan kata tersebut untuk menunjukkan acuan dalam kalimat. Dari uraian tersebut, pembetulannya dapat dilihat sebagai berikut.

Nur Rahma diduga melanggar undangundang Pasal 521 yang berbunyi: setiap pelaksana, peserta dan atau tim kampanye yang dengan sengaja melanggar larangan kampanye seperti yang dimaksud pasal 280 ayat 1 . Caleg DPR RI dari Partai Gerindra tersebut melakukan kegiatan kampanye di Masjid Baitus Syukur di Desa Gonilan, Kecamatan Kartasura beberapa waktu lalu.

\section{Data 4}

Dijelaskan Zamroni, puluhan Supeltas ini sudah terdata di Satlantas Polres Sukoharjo. Sehingga jika nanti terdapat Supeltas yang kurang berkenan di hati masyarakat, Zamroni meminta agar melaporkan hal itu kepadanya

Kesalahan penggunaan konjungsi juga terdapat pada kutipan di atas. Dalam kalimat tersebut kesalahan konjungsi terdapat pada penggunaan kata sehingga yang berada di awal kalimat. Penggunaan konjungsi sehingga tidak benar jika ditulis di awal kalimat karena bukan termasuk konjungsi yang digunakan untuk menghubungkan antar-kalimat. Konjungsi sehingga merupakan jenis konjungsi subordinatif yang digunakan untuk menghubungkan pernyataan sebab akibat untuk 
Ferdian Achsani: Kesalahan Berbahasa pada Penulisan Berita Online Sorot Sukoharjo...

menguhubungkan dua frasa klausa atau kalimat pada sebuah kalimat. Pembetulan terhadap kesalahan berbahasa tersebut dapat dilihat sebagai berikut.

Dijelaskan Zamroni, puluhan Supeltas ini sudah terdata di Satlantas Polres Sukoharjo. Jika terdapat Supeltas yang kurang berkenan di hati masyarakat, Zamroni meminta agar melaporkan hal itu kepadanya

\subsection{Kesalahan Ejaan}

\subsubsection{Kesalahan Tanda Titik}

\section{Data 5}

Dilanjutkan Heru, razia ini sendiri disamping untuk menjaga kondusifitas wilayah dalam menghadapi Ramadhan $1440 \mathrm{H}$. Juga untuk menegakan Perda Nomor 21 Tahun 2016 tentang penanggulangan prostitusi dan perbuatan asusila.

Paragraf di atas termasuk kesalahan berbahasa pada tataran ejaan dan sintaksis. Adanya kesalahan ejaan pada paragraf di atas terdapat pada penggunaan tanda titik, sebagai pemisah antara kalimat satu dengan kalimat selanjutnya. Kesalahan titik tersebut berdampak pada kesalahan berbahasa pada kalimat selanjutnya, yang ditandai dengan penggunaan konjungsi juga di awal kalimat dan ketidaklengkapan isi kalimat yang ditandai dengan tidak adanya subjek pada kalimat tersebut. Pembetulan kalimat tersebut dapat dilakukan dengan menghapus penulisan tahun Hijriah (H) dan tanda titik (.) pada kalimat tersebut. Dengan dihapusnya penulisan tahun Hijriah $(\mathrm{H})$ dan tanda titik (.), kemudian kedua kalimat tersebut dirangkai menjadi satu agar menjadi kalimat yang yang lengkap. Selain itu, penulisan frasa ini sendiri pada kalimat tersebut juga tidak tepat karena tekesan bertee-tele. Kata ini pada frasa tersebut sudah merujuk pada kata razia sehingga tidak perlu ditambahkan kata sendiri.

Dilanjutkan Heru, di samping untuk menjaga kondusivitas wilayah dalam menghadapi Ramadan 1440 razia ini juga untuk menegakkan Perda Nomor 21 Tahun 2016 tentang penanggulangan prostitusi dan perbuatan asusila.

Data 6

Kendati demikian Ketua KPU Nuril Huda merasa keberatan jika pleno harus ditunda.Mengingat satu kotak dari 12 kotak sudah dibuka.

Sama dengan pembahasan sebelumnya, pada paragraf di atas juga terdapat kesalahan berbahasa pada aspek ejaan. Adanya kesalahan ejaan ini menyebabkan kesalahan berbahasa tataran sintaksis pada kalimat 2 yang ditandai dengan tidak adanya subjek pada kalimat tersebut. Kesalahan berbahasa tataran ejaan pada paragraf di atas ditandai dengan penggunaan tanda titik. Penggunaan tanda titik tersebut tidak tepat karena tidak seharusnya digunakan agar kedua kalimat menjadi jelas maksudnya dan mudah dipahami.

Kendati demikian, Ketua KPU Nuril Huda merasa keberatan jika pleno harus ditunda mengingat satu dari 12 kotak sudah dibuka.

\subsubsection{Penulisan Unsur Bahasa Asing}

Data 7

Memperingati HUT Kopassus ke 67, Grup 2 Kopassus Kartasura Jawa Tengah menggelar Komando Enduro Trail kelas regular, Minggu (5/5). Kegiatan yang mengambil start di lapangan Solo Baru, Grogol, Sukoharjo, turut diikuti oleh Komandan Jendral (Danjen) KOPASSUS Mayjen TNI I Nyoman Cantiasa.

\section{Data 8}

Ada dua kelas yang digelar dalam event ini yakni kelas privat start Sabtu (4/5/2019) pemberhentian di Tawangmangu, Karanganyar, kemudian finish di Lapangan Solobaru Sukoharjo hari Minggu. Sedangkan kelas regular diikuti 1800 an peserta start dan finish hari Minggu. 
Ferdian Achsani: Kesalahan Berbahasa pada Penulisan Berita Online Sorot Sukoharjo...

Dua paragraf di atas terdapat kesalahan berbahasa pada tataran ejaan. Kesalahan ejaan pada data di atas yaitu pada kalimat pertama penggunaan kata regular. Pada data 8, kesalahan berbahasa terdapat pada penulisan kata event dan finish yang tidak dicetak miring. Kata regular, event dan finish merupakan kata yang berasal dari bahasa Inggris. Kata regular dalam bahasa Indonesia diterjemahakn menjadi 'biasa', kata event dalam bahasa Indonesia berarti 'acara atau kegiatan', sedangkan kata finish dalam bahasa Indonesia memiliki arti 'selesai'. Penggunaan kata asing tersebut apabila ditulis sesuai dengan kaidah kebahasaan Indonesia seharusnya dicetak miring, tetapi dalam paragraf tersebut tidak dicetak miring sehingga dapat dikatakan sebagai bentuk kesalahan berbahasa.

Selain penulisan bahasa asing yang tidak tepat, penggunaan tanda hubung (-) seharusnya digunakan dalam menuliskan frasa ke 67 (ke-67). Frasa tersebut juga mengalami kesalahan strukturnya karena seakan-akan di Indonesia memiliki Kopassus berjumlah 67 atau bahkan bisa lebih. Padahal Indonesia hanya memiliki satu Kopassus. Untuk itu, penulisan ke-67 diubah dengan meletakkannya di belakang kata HUT. Penggunaan kata hubung yang kurang tepat juga terdapat pada penulisan angka yang diikuti dengan akhiran -an pada data 8. Seturut PUEBI, penulisan angka yang diikuti dengan akhiran -an ditulis serangkai dan diberi tanda hubung.

Sementara itu, penulisan kata regular dan finish juga dapat dikatakan sebagai kesalahan fonologi. Kesalahan ini dapat dilihat dari perubahan huruf vokal dan penambahan konsonan /h/. Dalam KBBI penulisan yang tepat, yaitu reguler dan finis. Adapun pembetulan dari kesalahan berbahasa tersebut dapat dilihat sebagai berikut.

Data 7

Memperingati HUT ke-67 Kopassus, Grup 2 Kopassus Kartasura Jawa Tengah menggelar Komando Enduro Trail kelas regular, Minggu (5/5). Kegiatan yang mengambil start di lapangan Solo Baru, Grogol, Sukoharjo, turut diikuti oleh Komandan Jendral (Danjen) KOPASSUS Mayjen TNI I Nyoman Cantiasa.

Data $8(a)$

Ada dua kelas yang digelar dalam event ini, yakni kelas privat start Sabtu (4/5/2019) pemberhentian di Tawangmangu, Karanganyar, kemudian finish di Lapangan Solobaru Sukoharjo hari Minggu, sedangkan kelas regular diikuti 1800 -an peserta yang dimulai dan berakhir hari Minggu.

(b)

Ada dua kelas yang digelar dalam acara ini, yakni kelas privat start Sabtu (4/5/2019) pemberhentian di Tawangmangu, Karanganyar, kemudian finis di Lapangan Solobaru Sukoharjo hari Minggu, sedangkan kelas regular diikuti 1800 -an peserta yang dimulai dan berakhir hari Minggu.

\subsubsection{Penulisan Huruf Kapital}

\section{Data 9}

Ketua KPU Sukoharjo, Nuril Huda mengatakan, meskipun pleno di tingkat Kabupaten molor namun hal tersebut justru menunjukkan semua masalah terbuka, sehingga tidak ada kecurangan atau rekayasa.

Kesalahan berbahasa pada tataran ejaan pada kalimat di atas terdapat pada penggunaan kata Kabupaten. Penulisan kata tersebut seharusnya tidak perlu konsonan /K/ ditulis dengan huruf kapital karena tidak menunjukkan nama kabupaten. Namun, apabila dalam kutipan tersebut menunjukkan nama kabupaten, seharusnya ditulis dengan huruf kapital pada konsonan /K/. Adapun pembetulan dari kesalahan berbahasa tersebut dapat dilihat sebagai berikut.

Ketua KPU Sukoharjo, Nuril Huda mengatakan, meskipun pleno di tingkat kabupaten molor, hal tersebut justru menunjukkan semua masalah terbuka, 
Ferdian Achsani: Kesalahan Berbahasa pada Penulisan Berita Online Sorot Sukoharjo...

sehingga tidak ada kecurangan atau rekayasa.

Data 10

Selain berorasi dan pembacaan pres release, para peserta aksi juga melakukan Pembagian Takjil kepada pengguna jalan serta membagi - bagikan bunga untuk masyarakat yang melintas.

Kesalahan penulisan huruf kapital juga ditemukan pada kutipan di atas. Dalam kutipan tersebut penulisan Pembagian Takjil terjadi kesalahan dalam penggunaan huruf kapital. Kalimat tersebut tidak menyatakan tempat ataupun nama, tidak berada di awal kalimat, ataupun yang lainnya, tetapi menggunakan huduf kapital di tengah-tengah kalimat. Penggunaan huruf kapital tersebut dapat dikatakan sebagai bentuk kesalahan berbahasa. Adapun pembetulan terhadap kalimat tersebut dapat dilihat sebagai berikut.

Selain berorasi dan pembacaan pres release, para peserta aksi juga melakukan pembagian takjil kepada pengguna jalan serta membagi - bagikan bunga untuk masyarakat yang melintas.

\subsection{Kesalahan Fonologi}

\subsubsection{Penambahan Fonem}

\section{Data 11}

$\mathrm{Di}$ Indonesia budaya menyalakan petasan atau mercon selama bulan Ramadhan masih sering dilakukan.Oleh sebab itu jajaran Polres Sukoharjo terus melakukan upaya-upaya cipta kondisi.

Pada data di atas kesalahan berbahasa terdapat pada penggunaan kata Ramadhan. Dalam KBBI, penulisan kata ramadhan tidak menggunakan konsonan /h/ sehingga kata ramadhan ditulis Ramadan. Dari kesalahan tersebut dapat dikatakan bahwa kalimat tersebut terdapat kesalahan berbahasa pada tataran fonologi, yaitu pada penambahan konsonan /h/. Selain itu, kesalahan juga terdapat pada spasi yang tidak digunakan setelah tanda baca titik. Setelah tanda titik, untuk memulai kalimat baru hendaknya menggunakan spasi dan diawali dengan penggunaan huruf kapital. Akan tetapi, kalimat tersebut tidak menggunakan spasi setelah penggunaan tanda baca titik. Pembetulan dari kesalahan berbahasa tersebut dapat dilihat sebagai berikut.

Di Indonesia budaya menyalakan petasan atau mercon selama bulan

Ramadan masih sering dilakukan. Oleh sebab itu, jajaran Polres Sukoharjo terus melakukan upaya-upaya cipta kondisi.

Data 12

Ada beberapa jenis kebutuhan pokok yang digelar di pasar murah ini seperti beras, gula pasir, minyak goreng, tepung terigu, syirup, cabe merah, bawang merah dan bawang putih.

Selain kesalahan dalam penulisan kata Ramadan yang mengalami penambahan konsonan $/ \mathrm{h} /$, penulisan kata sirup pada kutipan di atas juga terdapat penambahan fonem pada fonem $/ \mathrm{y} /$ dan terjadi perubahan fonem /o/ menjadi / $\mathrm{u} /$. Dalam KBBI, penulisan kata syirup tidak menggunakan huruf /y/ dan /u/ sehingga kata syirup ditulis sirop. Pembetulan terhadap kesalahan berbahasa pada kalimat tersebut dapat dilihat sebagai berikut.

Ada beberapa jenis kebutuhan pokok yang digelar di pasar murah ini seperti beras, gula pasir, minyak goreng, tepung terigu, sirop, cabe merah, bawang merah dan bawang putih.

\subsubsection{Peleburan Fonem \\ Data 13 \\ Nur Rahma diduga melanggar undang- undang Pasal 521 yang bebunyi setiap pelaksana, peserta dan atau tim kampanye yang dengan sengaja melanggar larangan kampanye seperti yang dimaksud pasal 280 ayat 1 .}

Kesalahan berbahasa pada kalimat di atas terdapat pada penulisan kata bebunyi. Kata tersebut seharusnya ditulis berbunyi. Menghilangnya konsonan / $/$ / pada kata tersebut sebagai penanda terjadinya kesalahan berbahasa pada tataran fonologi 
Ferdian Achsani: Kesalahan Berbahasa pada Penulisan Berita Online Sorot Sukoharjo...

yang ditandai dengan meleburnya konsonan

$/ r /$. Adapun pembetulan terhadap kata tersebut dapat dilihat sebagai berikut.

Nur Rahma diduga melanggar undangundang Pasal 521 yang berbunyi: setiap pelaksana, peserta dan atau tim kampanye yang dengan sengaja melanggar larangan kampanye seperti yang dimaksud pasal 280 ayat 1 .

Data 14

Beberapa perira yang mengalami pergeseran antar lain, Wakapolres Sukoharjo sebelumnya dijabat Kompol Ifan Hariyat diganti oleh Kompol I Komang Sarjana.

Kesalahan berbahasa yang hadir pada kalimat di atas ditandai dengan penulisan kata perira yang seharusnya ditulis perwira. Dalam kalimat tersebut, penulis ingin melaporkan bahwa terjadi beberapa perwira yang mengalami pergeseran. Hadirnya peleburan konsonan /w/ pada kata tersebut menandakan terjadinya kesalahan berbahasa pada kata tersebut. Pembetulan dari kesalahan kata tersebut dapat dilihat sebagai berikut.

Beberapa perwira yang mengalami pergeseran antar lain, Wakapolres Sukoharjo sebelumnya dijabat Kompol Ifan Hariyat diganti oleh Kompol I Komang Sarjana.

\subsection{Kesalahan Morfologi \\ Data 16 \\ Sejumlah kendaraan, baik sepeda motor, mobil pribadi, mobil penumpang umum, maupun angkutan barang di hentikan untuk diperiksa satu-persatu}

Kesalahan berbahasa pada bentukan kata terdapat pada kalimat di atas. Dalam kalimat tersebut kesalahan bentukan kata ditandai dengan penggunaan kata di hentikan yang seharusnya ditulis serangkai, tapi dalam penulisan tersebut dipisah. Hal ini disebabkan oleh penggunaan kata di yang seharusnya dipisah apabila menunjukkan tempat dan penggunaan kata di digabung apabila menunjukkan kata kerja. Pada kalimat tersebut kata di hentikan seharusnya digabung karena menunjukkan imbuhan kata kerja. Selain itu, penulisan satu-persatu juga termasuk kesalahan berbahasa tataran ejaan karena menggunakan tanda hubung (-). Sesuai PUEBI, penulisan partikel per tidak perlu menggunakan tanda hubung (-). Perbaikan kata tersebut dapat dilihat sebagai berikut.

Sejumlah kendaraan, baik sepeda motor, mobil pribadi, mobil penumpang umum, maupun angkutan barang dihentikan untuk diperiksa satu per satu

Data 17

Diungkapkan Kombes Tri, untuk kemungkinan kondisi kedepan, pihaknya belum bisa memprediksi. Karena perkembangan dan ketahanan tubuh setiap orang berbeda-beda.

Berbeda dengan kutipan sebelumnya, pada kutipan di atas kesalahan berbahasa terdapat pada penggunaan partikel ke yang tidak tepat. Sama dengan penggunaan partikel di, penggunaan partikel ke yang menunjukkan tempat seharusnya juga dipisah. Namun, pada kutipan di atas, penulisan kata kedepan justru ditulis serangkai sehingga menyebabkan kesalahan berbahasa. Adapun pembetulan terhadap penulisan tersebut dapat dilihat sebagai berikut.

Diungkapkan Kombes Tri, untuk kemungkinan kondisi ke depan, pihaknya belum bisa memprediksi. Karena perkembangan dan ketahanan tubuh setiap orang berbeda-beda.

\section{SIMPULAN}

Penulisan berita, baik itu berita cetak ataupun berita online, perlu memperhatikan kaidah penggunaan bahasa. Hal ini bertujuan agar fakta yang disampaikan tidak ambigu. Selain itu, penggunaan kaidah bahasa yang baik dan benar juga berpengaruh terhadap kualitas sebuah berita. Berdasarkan uraian yang telah dijabarkan tersebut, dapat disimpulkan bahwa masih ditemukan 
Ferdian Achsani: Kesalahan Berbahasa pada Penulisan Berita Online Sorot Sukoharjo...

beberapa kesalahan-kesalahan berbahasa pada penulisan berita di media online Sorot Sukoharjo. Kesalahan-kesalahan berbahasa tersebut meliputi kesalahan pada tataran sintaksis, ejaan, dan fonologi. Pada tataran sintaksis tiga data (kesalahan kata satu data, kesalahan penggunaan subjek satu data, kesalahan konjungsi satu data), tataran ejaan lima data (meliputi kesalahan penggunaan tanda titik dua data, kesalahan penulisan bahasa asing dua data, kesalahan penulisan huruf kapital satu data), dan kesalahan tataran fonologi tiga data (meliputi keesalahan penambahan fonem satu data, peleburan fonem satu data, pengulangan fonem satu data). Berdasarkan uraian tersebut dapat disimpulkan bahwa kesalahan ejaan merupakan kesalahan berbahasa yang paling dominan ditemukan dalam penulisan berita di media online Sorot Sukoharjo.

\section{DAFTAR PUSTAKA}

Bugin, Bugin.2003. Analaisis Data Penelitian Kualitatif. Jakarta: PT Rajagrafindo Persada.

Darsita.2014. Penggunaan Kalimat Bahasa Indonesia oleh Mahasiswa Penutur Bahasa Asing. Al-Turās, Volume 20 Nomor 2, hlm. 245-258.

Hestiyana.2018. Bentuk Kesalahan Berbahasa pada Penulisan Iklan Media Luar Ruang di Kota Pelaihari. Sirok Bastra, Volume 6 Nomor 1, hlm. 81-92.

Inderasari, Elen., \& Tiya, Agustina.2017. Pembelajaran Bahasa Indonesia pada Mahasiswa Asing dalam Program BIPA IAIN Surakarta. Jurnal Pendidikan Bahasa Dan Sastra Indonesia, Volume 6 Nomor 2, hlm. 6-15.

Kusumaningsih, Dewi., dkk.2013. Terampil Berbahasa Indonesia: Mata Kuliah
Pengembangan Kepribadian. Yogyakarta: Penerbit Andi.

Mahsun.2012. Metode Penelitian Bahasa: Tahapan Steategi, Metode, dan Tekniknya (Edisi Revi). Jakarta: PT Raja Grafindo Persada.

Muhtadi, Asep Saeful.2016. Pengantar IImu Jurnalistik. Bandung: Simbiosa Rekatama Media.

Nurida.2016. Analisis Kesalahan Berbahasa Pada Surat Kabar Kendari Pos. Jurnal Bastra, Volume 3 Nomor 3, hlm. 1-13.

Oktaviani, Feny., Muhammad, Rohmadi., \& Purwadi. 2018. Analisis Kesalahan Berbahasa Indonesia pada Karangan Eksposisi Siswa Kelas X MIPA (Studi Kasus di Sma Negeri 4 Surakarta). BASASTRA Jurnal Penelitian Bahasa, Sastra Indonesia Dan Pengajarannya, Volume 6 Nomor 3, hlm. 94-109.

Putri, Silvia Wina., Erizal, Gani., \& Syahrul, R.2019. Penggunaan Prinsip Kesantunan Berbahasa dalam Talk Show Mata Najwa Edisi "100 Hari Anies-Sandi Memerintah Jakarta." Lingua, Volume 15 Nomor 1, hlm. 76-84.

Ramaniyar, Eti. 2017. Analisis Kesalahan Berbahasa Indonesia pada Penelitian Mini Mahasiswa. Jurnal Edukasi,Voume 15 Nomor 1, hlm. 70-80.

Setyawati, Nanik.2010. Analisis Kesalahan Berbahasa Indonesia: Teori dan Praktik. (M. Rohmadi, Ed.). Surakarta: Yuma Pustaka.

Widianingsih, Retno. Kurniasari.2014. Analisis Kesalahan Ejaan Pada Buku Teks Mata Pelajaran Bahasa Indonesia Untuk Kelas VI Sekolah Dasar Terbitan Yudhistira dan Erlangga. Universitas Negeri Yogyakarta. 